\title{
Autoantibodies against galectin-2 peptides as biomarkers for the antiphospholipid syndrome
} C Janko, S André, LE Munoz, JP Briand, C Schorn, S Winkler, M Schiller, L Andreoli, AA Manfredi, DA Isenberg, G Schett, HJ Gabius, S Muller and M Herrmann Lupus 2012 21: 781

DOI: $10.1177 / 0961203312443422$

The online version of this article can be found at:

http://lup.sagepub.com/content/21/7/781

\author{
Published by: \\ (9)SAGE \\ http://www.sagepublications.com
}

Additional services and information for Lupus can be found at:

Email Alerts: http://lup.sagepub.com/cgi/alerts

Subscriptions: http://lup.sagepub.com/subscriptions

Reprints: http://www.sagepub.com/journalsReprints.nav

Permissions: http://www.sagepub.com/journalsPermissions.nav

>> Version of Record - May 25, 2012

What is This? 


\title{
Autoantibodies against galectin-2 peptides as biomarkers for the antiphospholipid syndrome
}

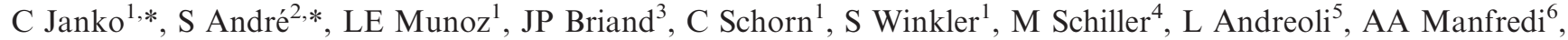 \\ DA Isenberg ${ }^{7}, \mathrm{G} \mathrm{Schett}^{1}$, HJ Gabius ${ }^{2, \#}, \mathrm{~S} \mathrm{Muller}^{3, \#}$ and M Herrmann ${ }^{1, \#}$ \\ ${ }^{1}$ Department of Internal Medicine 3, Friedrich-Alexander-University Erlangen-Nuremberg, Erlangen, Germany; ${ }^{2}$ Institute of Physiological \\ Chemistry, Faculty of Veterinary Medicine, Ludwig-Maximilians-University Munich, Munich, Germany; ${ }^{3}$ Centre National de la Recherche \\ Scientifique, Institut de Biologie Moléculaire et Cellulaire, Strasbourg, France; ${ }^{4}$ Department of Medicine V, University of Heidelberg, Heidelberg, \\ Germany; ${ }^{5}$ Rheumatology and Clinical Immunology, Spedali Civili, University of Brescia, Brescia, Italy; ${ }^{6}$ Hospital San Raffaele Scientific Institute \\ and University Vita-Salute San Raffaele, Milano, Italy; and ${ }^{7}$ Department of Medicine, Centre for Rheumatology, University College London, \\ London, UK
}

\begin{abstract}
Autoantibodies against opsonins of dying and dead cells mediate Fc $\gamma$ receptor-dependent phagocytosis of autologous apoptotic and necrotic cells and hereby tend to elicit inflammation instead of silent clearance. We analysed sera of patients with chronic autoimmune diseases for the occurrence of $\operatorname{IgG}$ autoantibodies recognizing galectins. These pluripotent effectors can also bind to apoptotic or necrotic cells. Patients with antiphospholipid syndrome (APS; $n=104$ ) and systemic lupus erythematosus (SLE; $n=62$ ) were examined, healthy donors $(n=31)$ served as controls. Selected peptides of galectin (Gal)-2 were employed for peptidebased ELISAs. Levels of anti-Gal-2 ${ }^{\mathrm{PEP}}$-IgG were significantly increased in SLE and APS when compared with controls. In addition, patients with APS showed significantly higher levels of anti-Gal-2 ${ }^{\mathrm{PEP}}$-IgG compared with patients with SLE. Anti-Gal-2 ${ }^{\mathrm{PEP}}$ - $\mathrm{IgG}$ may, therefore, be considered novel biomarkers for APS. Lupus (2012) 21, 781-783.
\end{abstract}

Key words: antiphospholipid syndrome; autoantibodies; lectins; systemic lupus erythematosus

\section{Introduction}

A fast and effective clearance of dying and dead cells is essential to prevent secondary necrosis, accompanied by leakage of autoantigens and inflammation. ${ }^{1}$ Compounds from uncleared cells have been discussed to elicit production of autoantibodies in chronic inflammatory diseases. ${ }^{2}$ To ensure silent clearance of apoptotic cells, a plethora of soluble adaptor molecules assists in bridging dying cells to phagocytes. Galectins (Gal), a family of endogenous lectins sharing galactoside specificity and sequence signature/folding, ${ }^{3,4}$ bind apoptotic and necrotic cells and an involvement in clearance for Gal-3 is suggested. ${ }^{5,}{ }^{6}$ For interest,

\footnotetext{
*These authors contributed equally to the work.

\#These authors contributed equally to the senior authorship.

Correspondence to: Professor Martin Herrmann, Krankenhausstraße 12, 91054 Erlangen, Germany

Email: martin.herrmann@uk-erlangen.de
}

opsonins (e.g. Gal) can often become targets of an adaptive humoral immune response followed by autoimmune disease. ${ }^{7,8}$ To address this issue for Gal we analysed anti-Gal-IgG in patients with systemic lupus erythematosus (SLE) and antiphospholipid syndrome (APS) employing peptidebased ELISAs.

\section{Patients and methods}

Sera were processed from 104 patients with primary or secondary APS, 62 patients with SLE, and 31 healthy blood donors (HBDs) who served as controls. Patients were diagnosed as APS according the revised classification criteria for APS. ${ }^{9}$ Patients classified as SLE met the classification criteria of the American College of Rheumatology for SLE. ${ }^{10}$ Clinical manifestations and serological parameters of the patients are compiled in Table 1 . Three chemically synthesized Gal-2 derived 
Table 1 Clinical manifestations and serological parameters of the patients

\begin{tabular}{|c|c|c|c|c|c|c|c|c|c|c|c|}
\hline \multirow[b]{2}{*}{ Diagnosis } & \multirow[b]{2}{*}{$\begin{array}{l}\text { Number } \\
\text { of } \\
\text { patients }\end{array}$} & \multirow[b]{2}{*}{$\begin{array}{l}\text { sex } \\
\text { [female } \\
\% \text { ] }\end{array}$} & \multirow[b]{2}{*}{$\begin{array}{l}\text { age [years; } \\
\text { mean } \pm \\
\text { standard } \\
\text { deviation] }\end{array}$} & \multicolumn{4}{|c|}{ Clinical manifestations } & \multicolumn{3}{|c|}{ Serological parameters } & \multirow[b]{2}{*}{$\begin{array}{l}\text { category I; } \\
\text { (more than } \\
\text { one laboratory } \\
\text { criteria present) }\end{array}$} \\
\hline & & & & $\begin{array}{l}\text { thrombotic event } \\
\& \text { pulmonary } \\
\text { embolism }\end{array}$ & $\begin{array}{l}\text { obstetric } \\
\text { complica- } \\
\text { tions }\end{array}$ & $\begin{array}{l}\text { cerebral } \\
\text { vascular } \\
\text { event }\end{array}$ & $\begin{array}{l}\text { Raynaud- } \\
\text { Syndrome }\end{array}$ & $\begin{array}{l}\text { Lupus } \\
\text { anti- } \\
\text { coagulant }\end{array}$ & $\begin{array}{l}\text { anti-CL } \\
(\operatorname{Ig} G \text { or } \\
\operatorname{Ig} M)\end{array}$ & $\begin{array}{l}\text { anti- } \beta 2 G P 1 \\
\text { (IgG or } \\
\operatorname{Ig} M)\end{array}$ & \\
\hline APS & 104 & 80.8 & $46.0 \pm 12.0$ & 59 & 32 & 13 & 13 & 56 & 72 & 47 & 49 \\
\hline SLE & 62 & 83.9 & $40.4 \pm 14.3$ & 0 & 0 & 0 & 0 & 0 & 15 & 0 & 0 \\
\hline
\end{tabular}

APS patients met the revised classification criteria for APS, ${ }^{9}$ SLE patients met the classification criteria of the American College of Rheumatology for SLE. ${ }^{10}$

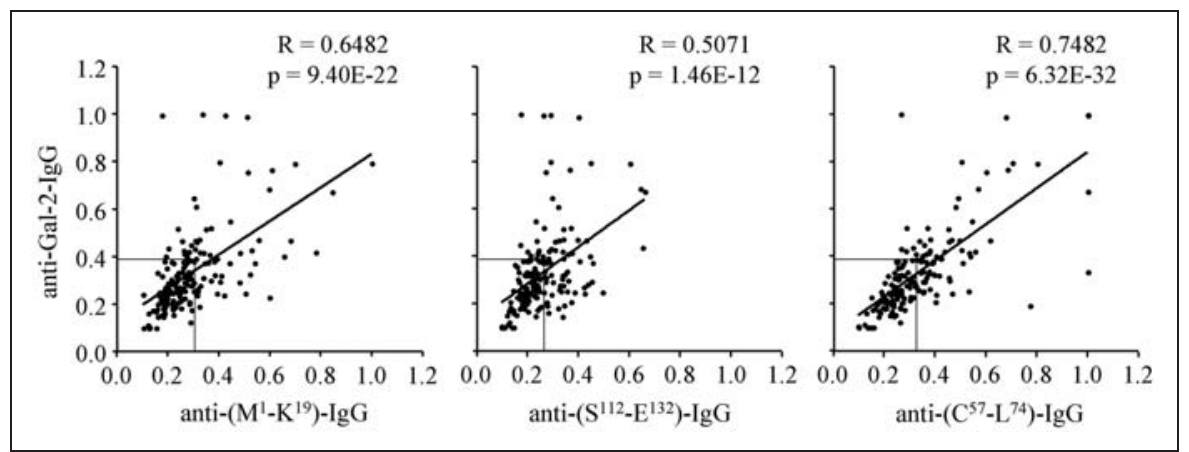

Figure 1 Autoantibodies against Gal-2 and the corresponding Gal-2-derived peptides correlate in sera of patients with SLE and APS. $R$ and $p$-values of the Spearman-rho correlations are indicated. The cut-off levels (99th percentile of the HBD) were inserted as boxes into the graphs. Amino acid sequences are shown in http://www.ncbi.nlm.nih.gov/protein/NP_006489.1. The sequences of the Gal-2 peptides are: MTGELEVKNMDMKPGSTLK $\left(\mathrm{M}^{1}-\mathrm{K}^{19}\right)$, CNSLDGSNWGQEQREDHL $\left(\overline{\mathrm{C}}^{57}-\mathrm{L}^{74}\right)$, and SHLSYLSVR GGFNMSSFKLKE $\left(\mathrm{S}^{112}-\mathrm{E}^{132}\right)$.

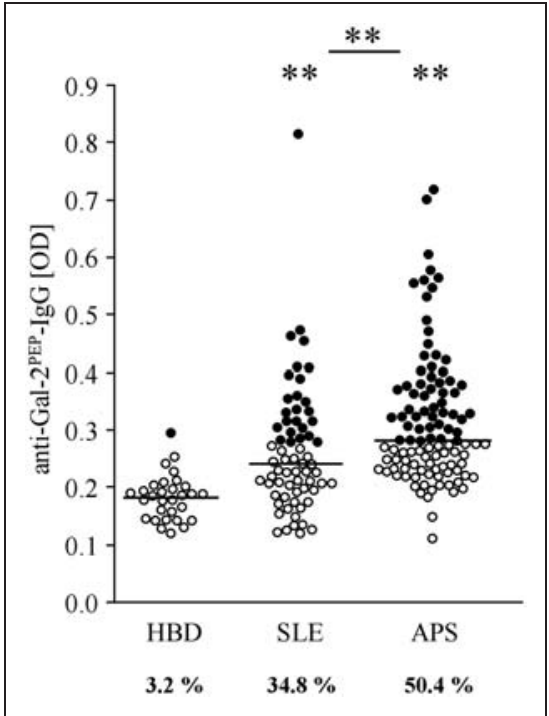

Figure 2 Patients with APS and SLE show increased levels of anti-Gal-2 ${ }^{\text {PEP }}$-IgG. Anti-Gal-2 ${ }^{\text {PEP }}$-IgG were measured by ELISA, displayed are the mean values of the three anti-Gal$2^{\text {PEP}}$-IgG. The 99th percentile of the HBD was set as cut-off value (open circles $<99$ th; closed circles $>99$ th percentile of the HBD). Indicated are the percentages of the patients with Gal$2^{\text {PEP }}$-IgG $>$ cut-off value. The horizontal bar represents the median values of one cohort. HBD, healthy blood donor; SLE, systemic lupus erythematosus; APS, antiphospholipid syndrome. Significances were calculated by Mann-Whitney $U$ tests. ${ }^{* *} p<0.01$. peptides, namely a N-terminal 19 mer $\left(\mathrm{M}^{1}-\mathrm{K}^{19}\right)$, a central $18 \mathrm{mer}\left(\mathrm{C}^{57}-\mathrm{L}^{74}\right)$ and a $\mathrm{C}$-terminal $21 \mathrm{mer}$ $\left(\mathrm{S}^{112}-\mathrm{E}^{132}\right)$ were tested. ${ }^{11}$ The full-size Gal-2 was obtained by recombinant production and purified by affinity chromatography. ${ }^{12}$ Anti-Gal-2 IgG in sera of autoimmune patients were detected by ELISAs. The cut-off level was defined as the 99th percentile of the optical density (OD) values of HBD. Experimental values are expressed as mean OD of the duplicates of each serum. SPSS 17.0 software was used for statistic calculations.

\section{Results and discussion}

We compared the reactivity of $\mathrm{IgG}$ autoantibodies against the three Gal-2 peptides in sera of patients with SLE and APS with the reactivity against the recombinant protein. A significant correlation (Spearman) of the peptide reactivity with that of the corresponding full-size protein was obtained (Figure 1). Compared with HBD controls significantly increased IgG-antibody levels against Gal-2 ${ }^{\text {PEP }}$ were found in patients with APS and SLE (Figure 2). Interestingly, the anti-Gal-2 $2^{\mathrm{PEP}}$ $\mathrm{IgG}$ in the APS cohort was significantly increased 
when compared with the SLE cohort containing no patients with APS. Anti-Gal-2 ${ }^{\mathrm{PEP}}$-IgG may, therefore, be considered as novel biomarkers for APS.

\section{Funding}

This work was supported by the Masterswitch project of the EU, the DFG (training grant SFB 643), the Interdisciplinary Center of Clinical Research (IZKF, grant number TP A41) at the University Hospital of the University of ErlangenNuremberg, the K\&R Wucherpfennig Stiftung, the EC (GlycoHIT, grant number 260600), and CNRS (to JPB and SM).

\section{Conflict of interest}

The authors declare no conflict of interest.

\section{References}

1 Schulze C, Munoz LE, Franz S, et al. Clearance deficiency-a potential link between infections and autoimmunity. Autoimmun Rev 2008; 8: 5-8.

2 Munoz LE, Lauber K, Schiller M, et al. The role of defective clearance of apoptotic cells in systemic autoimmunity. Nat Rev Rheumatol 2010; 6: 280-289.
3 Gabius HJ, Andre S, Jimenez-Barbero J, et al. From lectin structure to functional glycomics: principles of the sugar code. Trends Biochem Sci 2011; 36: 298-313.

4 Kaltner $\mathrm{H}$, Gabius $\mathrm{H}$. A toolbox of lectins for translating the sugar code: the galectin network in phylogenesis and tumors. Histol Histopathol 2012; in press.

5 Beer A, Andre S, Kaltner H, et al. Human galectins as sensors for apoptosis/necrosis-associated surface changes of granulocytes and lymphocytes. Cytometry A 2008; 73: 139-147.

6 Karlsson A, Christenson K, Matlak M, et al. Galectin-3 functions as an opsonin and enhances the macrophage clearance of apoptotic neutrophils. Glycobiology 2009; 19: 16-20.

7 Massardo L, Metz C, Pardo E, et al. Autoantibodies against galectin-8: their specificity, association with lymphopenia in systemic lupus erythematosus and detection in rheumatoid arthritis and acute inflammation. Lupus 2009; 8: 539-546.

8 Janko C, Franz S, Munoz L, et al. CRP/anti-CRP antibodies assembly on the surfaces of cell remnants switches their phagocytic clearance toward inflammation. Front Immun 2011;2.

9 Miyakis S, Lockshin MD, Atsumi T, et al. International consensus statement on an update of the classification criteria for definite antiphospholipid syndrome (APS). J Thromb Haemost 2006; 4: 295-306.

10 Hochberg MC. Updating the American College of Rheumatology revised criteria for the classification of systemic lupus erythematosus. Arthritis Rheum 1997; 40: 1725.

11 Neimark J, Briand JP. Development of a fully automated multichannel peptide synthesizer with integrated TFA cleavage capability. Pept Res 1993; 6: 219-228.

12 Andre S, Kaltner H, Lensch M, et al. Determination of structural and functional overlap/divergence of five proto-type galectins by analysis of the growth-regulatory interaction with ganglioside GM1 in silico and in vitro on human neuroblastoma cells. Int $J$ Cancer 2005; 114: 46-57. 